\title{
PELAYANAN MATERNAL PADA PERIODE INTRANATAL DI RUMAH SAKIT TIPE B TAHUN 2019
}

\section{Darmayanti}

Akademi keperawatan RS. Dustira Cimahi Jawa Barat,Indonesia

Email: darmasofyan41@gmail.com

\section{Abstract}

The purpose of the study was to obtain an overview of how the intranatal service process is carried out and explore the views of health workers on individual problems and barriers to the services provided. The research design uses mixed methods with sequential explanatory models. The research mapma stage uses quantitative methods to find out the picture of maternity nursing care services at Dustira Cimahi Hospital using observation sheets and questionnaires that are analyzed univariately. The sample numbered 16 people, using stratified random sampling proportionalization techniques. The second phase using qualitative method using interview technique to health officer numbered 4 participants to strengthen quantitative data and analyzed descriptive qualitatively using data analysis stages miles and huberman model. Data collection was carried out from June-July 2019. The results of the study obtained data that nursing care services (Askep) Maternitas in spontaneous intranatal services obtained data, an average of $92.73 \%$ with a range between $90.91 \%$ - 95.45\%, while in SC patients the average service that has been given is only $86.2 \%$ of all service processes with a range between $80 \%$ - 96\%. While the average quality of service based on the element of satisfaction of patients in spontaneous intranatal is $70.7 \%$ and in intranatal SC $71.8 \%$. It can be concluded that the service process in the intranal period in one of the hospitals. Type B Cimahi city is not optimal, or there are still some that have not been implemented in accordance with the standards and have not reached the target of $100 \%$ service standards while patient satisfaction shows that the quality of intranatal services in hospitals. Dustira is in the good category. The advice in this study is to implement maternity nursing care services that are integrated with midwifery services.

Keywords: intrantal maternity nursing careservices; standard of hospital services; patient and officer perspectives

\section{Abstrak}

Tujuan penelitian adalah memperoleh gambaran tentang bagaimana proses pelayanan intranatal dikerjakan dan mengeksplorasi pandangan petugas kesehatan mengenai masalah dan hambatan secara individual terhadap pelayanan yang diberikan. Rancangan penelitian menggunakan metode kombinasi (mixed methods) dengan model sequential explanatory. Tahap petama penelitian menggunakan metode kuantitatif untuk mengetahui gambaran pelayanan asuhan keperawatan maternitas di RS Dustira Cimahi menggunakan lembar observasi dan kuesioner yang dianalisis secara univariat. Jumlah sampel 16 orang, menggunakan teknik 
proporsionate stratified random sampling. Tahap kedua dengan metode kualitatif menggunakan teknik wawancara ke petugas kesehatan berjumlah 4 partisipan untuk memperkuat data kuantitatif dan dianalisis secara deskriptif kualitatif menggunakan tahapan analisis data model Miles dan Huberman. Pengambilan data dilaksanakan dari bualan Juni-Juli 2019. Hasil peneltian didapatkan data bahwa pelayanan Asuhan Keperawatan (Askep) Maternitas pada pelayanan intranatal spontan didapatkan data, rata-rata $92,73 \%$ dengan rentang antara 90,91\%-95,45\%, sedangkan pada pasien SC rata-rata pelayanan yang telah diberikan hanya $86,2 \%$ dari semua proses pelayanan dengan rentang antara $80 \%-96 \%$. Sedangkan ratarata kualitas pelayanan berdasarkan unsur kepuasaan pasien pada intranatal spontan yaitu $70,7 \%$ dan pada intranatal SC $71.8 \%$. Dapat disimpulkan bahwa proses pelayanan pada periode intranal di salah satu RS. Tipe B Kota Cimahi ini belum optimal, atau masih ada beberapa yang belum dilaksanakan sesuai dengan standar dan belum mencapai target standar pelayanan sebesar $100 \%$ sedangkan kepuasan pasien menunjukan bahwa kualitas pelayanan intranatal di RS. Dustira berada pada kategori baik. Saran pada penelitian ini adalah menerapkan pelayanan asuhan keperawatan maternitas yang diintegrasikan dengan pelayanan kebidanan.

Kata kunci: pelayanan asuhan keperawatan maternitas intrantal; standar pelayanan rumah sakit; prespektif pasien dan petugas

\section{Pendahuluan}

Tingginya Angka Kematian Ibu (AKI) khususnya di negara berkembang termasuk Indonesia, menjadi salah satu masalah kesehatan di dunia. AKI di Indonesia masih tinggi yaitu pada tahun 2015 sebesar 305 per 100.000 kelahiran hidup. Berbagai upaya dilakukan pemerintah Indonesia salah satu diantaranya melalui pelayanan maternal untuk mencapai target program Sustainable Development Goals (SDGS) yaitu pada tahun 2030, mengurangi angka kematian ibu hingga di bawah 70 per 100.000. (UNPDF, 2016-2020). Kondisi saat ini Indonesia belum mencapai target pencampaian AKI seperti yang diharapkan. Kematian ibu di periode maternal salah satunya periode intranatal atau saat persalinan banyak terjadi di Rumah Sakit (RS), namun pada kenyataanya pelayanan yang diberikan RS belum optimal. Pernyataan ini didukung oleh penelitian Simbolon, (2013) yang berjudul Determinan Kinerja Pelayanan Kesehatan Ibu dan Anak di Rumah Sakit Pemerintah Indonesia. Penelitian tersebut menyebutkan bahwa kinerja pelayanan dalam bidang KIA sebagian besar $(66,3 \%)$ dari 685 RS pemerintah di Indonesia, masih kurang optimal. Pelayanan yang diberikan oleh RS dalam upaya menurunkan AKI yaitu melalui penyelenggaraan Pelayanan Keperawatan Ibu dan Anak, salah satunya pelayanan keperawatan maternitas (Kemenkes, 2015).

Pelayanan keperawatan maternitas di RS memiliki peran yang sangat strategis dalam upaya menurunkan AKI, karena RS merupakan institusi pelayanan kesehatan yang menyelenggarakan pelayanan kesehatan perorangan secara paripurna, meliputi promotif, preventif, kuratif dan rehabilitative (UU No. 44, 2009). RS juga merupakan fasilitas kesehatan rujukan dari fasilitas kesehatan tingkat I, untuk pasien maternal dengan komplikasi obstetric yang dialami oleh sekitar $20 \%$ dari seluruh ibu hamil, tetapi kasus komplikasi obstetrik yang ditangani secara baik kurang dari $10 \%$. RS 
memiliki andil besar dalam AKI karena sebanyak 53\% pasien mengalami pengambilan keputusan klinik yang tidak tepat, sebanyak $47 \%$ terlambat dilakukan eksekusi/operasi, dan $47 \%$ mengalami ketidakakuratan di dalam monitoring (Moog, Learning, \& Student-Centered, 2017).

Pelayanan keperawatan maternitas di RS ditujukan untuk meminimalkan komplikasi dan menurunkan risiko bagi ibu dan bayi termasuk dalam pelaksanaan asuhan keperawatan yang bertujuan membantu meningkatkan kesejahteraan ibu dan janin, bayi baru lahir dan membantu perkembangan keutuhan keluarga. Praktik pelayanan keperawatan maternitas meliputi pelayanan asuhan keperawatan yang meliputi masa antenatal, intranatal, postnatal, bayi baru lahir dan kesehatan reproduksi perempuan dengan memperhatikan aspek bio psiko sosio spiritual (Kemenkes, 2015). Perencanaan strategis masih diperlukan untuk meningkatkan pelayanan keperawatan dan kebidanan pada bidang maternal. Pernyataan ini didukung oleh penelitaian tentang Efektifitas dan Kepuasan Pasien pada Pelayanan Keperawatan Maternitas di RSHS bandung, yang menyimpulkan bahwa ada beberapa kekhawatiran berkaitan dengan efektifitas perawatan persalinan dengan tingkat kepuasan pasien 58\% puas dan $42 \%$ tidak puas (Rahayuwati, Ermiati, \& Trisyani, 2016).

Pelayanan asuhan keperawatan maternitas pada periode intrantal, merupakan salah satu faktor determinan dari kesakitan dan kematian maternal akibat komplikasi persalinan. Penelitian (Simarmata, Armagustini, \& Bisara, 2012) didapatkan hasil bahwa proporsi kejadian komplikasi persalinan yang mengancam keselamatan ibu dan janin di Indonesia antara kurun waktu tahun 2005-2010 sebanyak 47,8 \%. Pelayanan persalinan yang optimal merupakan salah satu cara menekan angka kesakitan dan kematian pada ibu dan bayi (Sari, 2014). Pelayanan persalinan yang optimal menurut pedoman Rumah Sakit Sayang Ibu dan Bayi diselenggarakan secara bersih dan aman, namun masih terbatas informasi tentang pelaksanaan pelayanan bersalin di RS baik persalinan normal ataupun dengan tindakan.

Pelayanan asuhan keperawatan pada area intranatal di RS sebagai bagian dari pelayanan bidang maternal diselenggarakan secara sistematis dan berjenjang mulai dari pelayanan kesehatan dasar sampai pelayanan rujukan dan terintegrasi dengan pelayanan kebidanan. Pelayanan maternal dilaksanakan secara langsung di bawah kementerian kesehatan dan swasta sesuai dengan peraturan kementerian kesehatan yang diklasifikasikan menjadi RS tipe A, B, C, dan D. Target pelayanan yang diberikan disesuaikan dengan tipe RS dalam upaya pencapaian indikator mutu pelayanan di RS diantaranya adalah jumlah kunjungan pasien ke RS dan tingkat kepuasaanya. Suatu dikatakan bermutu dalam dimensi tertentu apabila indikator pelayanan mencapai atau melampaui standar yang telah ditetapkan, sehingga diperlukan suatu strategi dalam pencapainnya. Pelayanan Keperawatan sebagai bagian integral dari pelayanan kesehatan memiliki peran dalam menjaga kualitas pelayanan yang bermutu. Evaluasi mengenai langkah-langkah atau strategi dalam pencapaian indikator mutu masih terbatas, sehingga program yang telah disusun belum dapat menganalisis bagaimana tingkat keberhasilannya. 
Pelaksanaan pelayanan intranatal di RS sebagai tempat rujukan, yaitu dengan memberikan pelayanan pada persalinan spontan dan penatalaksanaan persalinan buatan. Sifat perujukan dalam pelayanan kesehatan maternal dibedakan menjadi rujukan kegawatdaruratan dan rujukan berencana, dengan alasan tenaga dan perlengkapan fasilitas kesehatan dasar tidak mampu menangani komplikasi. Salah satu RS tipe B di kota Cimahi ini telah menyelenggarakan pelayanan bidang maternal yang secara operasional dilaksanakan oleh poliklinik kebidanan, Ruang Perawatan Nifas, Ruang Perawatan kasus obsteri dan gynekolog, ruang bersalin dan Pelayanan Obstetri Neonatal Emergensi Komprehensif (PONEK) dibawah Instalasi Gawat Darurat. Data yang berhubungan dengan perslinan pada RS tersebut pada 3 tahun terakhir mencapai 5105 persalinan dan 3250 atau sekitar $64 \%$ merupakan persalinan sectio caesaria (SC). Data tersebut menunjukan bahwa angka persalinan buatan lebih banyak daripada persalinan spontan, dengan kata lain data pasien intranatal yang memerlukan penanganan khusus akibat adanya indikasi SC atau adanya komplikasi lebih banyak daripada pasien intranatal tanpa komplikasi.

Indikator mutu pelayanan maternal di RS Tipe B dilaksanakan berdasarkan Standar Pelayanan Minimal RS diantaranya : 1) Kejadian kematian ibu dalam persalinan karena perdarahan $\leq 1 \%$, preeklamsia $\leq 30 \%$, dan sepsis $<0.2 \%, 2$ ) pemberi pelayanan persalinan adalah Dokter Sp.OG dan Dokter Umum yang telah terlatih (APN), serta oleh Bidan, 3) Pemberi pelayanan persalinan dengan penyulit dilaksanakan oleh tim PONEK terlatih, 4) Pemberi pelayanan persalinan dengan tindakan operasi oleh Dokter Sp.OG, Sp. A dan Sp.An, 5) Pertolongan persalinan SC dengan standar $\leq$ $20 \%$, dan 6) pencapaian kepuasan pelanggan $\geq 80 \%$. Suatu pelayanan dikatakan bermutu dalam dimensi tertentu apabila indikator pelayanan mencapai atau melampaui standar yang telah ditetapkan, sehingga diperlukan suatu strategi dalam pencapainnya.

Keperawatan sebagai bagian integral dari pelayanan kesehatan memiliki peran dalam menjaga kualitas pelayanan yang bermutu. Amanat Permenkes No 10 tahun 2015 tentang Standar Pelayanan Keperawatan Di RS Khusus, menyebutkan bahwa pelayanan maternal perlu didukung kompetensi memadai dari perawat pelaksana, perawat pengelola dan kebijakan yang berlaku. Pelaksanaan pelayanan maternal melalui penerpanan asuhan keperawatan terdiri dari serangakaian kegiatan yaitu pengkajian, penegakan diagnose keperawatan, penentuan intervensi, pelaksanaan tindakan (implementasi) dan evaluasi. Secara umum pelayanan asuhan keperawatan maternitas, merupakan bagian dari standar layanan kesehatan. Standar adalah suatu pernyataan diskriptif yang menguraikan penampilan kerja yang dapat diukur melalui kualitas struktur, proses dan hasil (Gillies, Lo, \& Wesolowski, 1989) Evaluasi mengenai langkah-langkah atau strategi dalam pencapaian indikator mutu dalam pelayanan maternal masih terbatas, sehingga program yang telah disusun belum dapat menganalisis bagaimana tingkat keberhasilannya.

Penelitian ini menggunakan penelitian mixmethode, yang bertujuan untuk memperoleh gambaran tentang bagaimana proses pelayanan intranatal dikerjakan dan mengeksplorasi pandangan petugas kesehatan mengenai masalah dan hambatan secara 
individual terhadap pelayanan yang diberikan. Selain itu, penelitian ini akan memberikan gambaran kepuasan pasien sebagai salah satu penilaian terhadap kualitas pelayanan intranatal. Sedangkan manfaat yang hendak dicapai dalam penelitin ini adalah manfaat dalam pengembangan proses analisis sebagai bahan masukan tentang kondisi real pelayanan asuhan keperawatan maternitas periode intranatal dan sebagai bahan kajian pustaka dan kerangka acuan serta memberikan informasi untuk pengembangan program dalam meningkatkan kualitas pelayanan.

\section{Metode Penelitian}

Penelitian menggunakan metode kombinasi (mixed methods) dengan model sequential explanatory yang bertujuan untuk membandingkan perspektif-perspektif berbeda yang diambil dari data kuantitatif dan kualitatif serta mendapatkan pemahaman tentang penerapan standar pelayanan asuhan keperawatan meternitas terhadap kepuasan pasien. untuk mendapatkan gambaran dua hal yang berbeda dilakukan dengan melakukan pengumpulan data secara kuantitatif dan kualitatif. Tahap pertama penelitian menggunakan metode kuantitatif pengumpulan data dimaksudkan untuk mengetahui bagaimana gambaran pelayanan asuhan keperawatan maternitas pada periode intranatal. Tahap kedua dengan metode kualitatif, pengumpulan data dimaksudkan untuk memperkuat data kuantitatif tentang pelayanan antenatal yang telah diperoleh pada tahap awal. Data kualitatif didapatkan dari petugas, kepala ruangan, dan manajemen bidang keperawatan berdasarkan data hasil penelitian kuantitatif. Pengumpulan data kualitatif dilaksanakan melalui wawancara semi terstruktur untuk memperkuat penelitian kuantitaif dengan menyusun pertanyaan berdasarkan hasil kuantitaif. Pada penelitian ini, penelitian kuantitatif, data dikuatkan secara kualitatif dan dari kedua data tersebut ditemukan gambaran secara menyeluruh tentang pelayanan intranatal di salah satu RS tipe B di Kota Cimahi.

Pelayanan intranatal di RS ini secara operasional dilaksanakan oleh ruang bersalin dengan kapasitas tempat tidur sebanyak 7 (tujuh) buah, dan ditunjang dengan alat pertolongan persalinan yang memadai. Selain itu, pelayanan intranatal didukung adanya ruang bedah untuk pertolongan persalinan secara sectio caesarea (SC) serta telah memiliki unit perinatologi. Ruang bersalin RS. Dustira memiliki SDM sebanyak 14 orang dengan kualifikasi pendidikan terendah adalah Diploma III (D3) kebidanan dan telah memiliki STR bidan.

Pengumpulan data pada penelitian ini dilaksanakan pada bulan Juni sampai dengan agustus 2019. Sumber data terbagi menjadi dua yaitu sumber data kuantitatif (populasi dan sampel), serta sumber data kualitatif (partisipan). Populasi dalam penelitian ini adalah pasien yang menerima pelayanan maternal di ruang bersalin periode intranatal. Sampel dalam penelitian ini yaitu sebagian pasien yang menjalani persalinan, yang diambil secara proporsionate stratified random sampling, jumlah sampel pada penelitian ini adala 14 orang. Sedangkan, Partisipan yang digunakan dalam metode kualitatif pada penelitian ini yaitu petugas kesehatan, kepala ruangan dan manajemen bidang keperawatan di fasilitas pelayanan intranatal RS tersebut yang 
dipilih secara purposive sampling yaitu mencari partisipan dengan pertimbangan tertentu diantaranya 1) Perawat atau bidan yang merupakan pegawai tetap di pelayanan Intranatal, 2) Kepala Poliklinik dan manajemen bidang keperawatan, 3) Masa kerja diatas 5 tahun dan berstatus sebagai PNS/Organik/Karyawan Tetap. 3) Pendidikan minimal D3 Kebidanan/ Perawatan. Jumlah pertisipan dalam penelitian kualitatif ini sebanyak 4 orang yang terdiri dari 2 petugas kesehatan, 1 kepala ruangan dan 1 kepala manajemen keperawatan.

Penelitian ini menggunakan dua instrument yaitu instrument kuantitaif dan kualitatif instrument kuantitatif berupa lembar observasi standar pelayanan asuhan keperawatan maternitas dan kuisioner kepuasan pasien terahadap pelayanan. Lembar observasi standar pelayanan asuhan keperawatan maternitas telah dilakukan uji content oleh expert judgement, sedangakan kuisioner kepuasan pelayanan merupakan kuisioner baku yang telah ditentukan oleh Kementerian Pendayagunaan Aparatur Negara dan Reformasi Birokrasi tentang pedoman umun indeks kepuasan masyarakat. Instrumen pada pengumpulan data kualitatif menggunakan panduan wawancara yang disusun berdasarkan data kuantitaif untuk mengetahui gambaran proses pelayanan asuhan keperawatan antenatal. Selain itu, peneliti menggunakan alat perekam untuk merekam semua informasi yang disampaikan oleh informan dan lembar observasi

Pengumpulan data diawali dengan pengambilan data kuantitatif, setelah subjek penelitian menandatangani lembar informed consent, selanjutnya peneliti melakukan observasi mengenai standar pelayanan asuhan keperawatan maternal yang diterima oleh pasien. Pelaksanaan observasi dilakukan dengan memantau kegiatan petugas berdasarkan standar pelayanan yang diberikan kepada responden. Tahap selanjutnya peneliti memberikan kuesioner dan diberikan penjelasan mengenai cara pengisian kuesionernya, sehingga subjek mengerti dan tidak bingung dalam pengisian kuesioner. Setelah semua proses data kuantitatif selesai dilakukan, dan telah memenuhi jumlah sampel, data kuantitatif diolah dan dianalisis. Setelah itu berdasarkan hasil analisis tersebut peneliti menyusun panduan wawancara, kemudian peneliti memulai tahapan kualitatif dengan melakukan wawancara kepada informan. Partisipan yang diwawancara yaitu bidang manajemen keperawatan untuk mengeksplorasi terkait dengan kebijakan dan standar pelayanan yang berlaku di RS tempat penelitian. Wawancara berikutnya kepada penanggung jawab ruang bersalin beserta 2 orang bidan pelaksana, wawancara dilakukan untuk memperoleh gambaran tentang bagaimana proses pemberian pelayanan pada periode intranatal spontan dan SC.

\section{Hasil dan Pembahasan}

a. Hasil Penelitian

1) Proses pelayanan asuhan keperawatan maternitas pada periode intranatal

Hasil penelitian tentang pelayanan Asuhan Keperawatan (Askep) Maternitas pada pelayanan intranatal spontan menunjukkan bahwa dari 5 pasien proses pelayanan yang diberikan, rata-rata $92,73 \%$ dengan rentang 
antara 90,91\% - 95,45\%. Pelaksanaan proses pelayanan pada masing-masing item observasi dilaporkan sebagai berikut :

Tabel 1

Gambaran proses pelayanan asuhan keperawatan maternitas pada intranatal spontan

\begin{tabular}{|c|c|c|c|c|}
\hline $\begin{array}{c}\text { Standar } \\
\text { Pelayanan }\end{array}$ & No & Item Observasi & Jumlah & $\%$ \\
\hline \multirow{12}{*}{$\begin{array}{l}\text { Asuhan } \\
\text { Intranatal }\end{array}$} & 1 & $\begin{array}{l}\text { a. Perawat atau bidan melakukan pengisian } \\
\text { format pengkajian dan format pemantauan } \\
\text { kemajuan persalinan (partograf), format } \\
\text { diagnosis, format perencanaan, format } \\
\text { implementasi dan format evaluasi. }\end{array}$ & 5 & 100 \\
\hline & 2 & $\begin{array}{l}\text { b. Perawat atau bidan melakukan pemantau } \\
\text { kesejahteraan janin dan ibu secara berkala }\end{array}$ & 5 & 100 \\
\hline & 3 & $\begin{array}{l}\text { c. Perawat atau bidan menentukan rencana } \\
\text { asuhan intranatal pada setiap kala persalinan } \\
\text { (Kala 1, 2, 3 dan 4) }\end{array}$ & 5 & 100 \\
\hline & 4 & $\begin{array}{l}\text { d. Perawat atau bidan melakukan pertolongan } \\
\text { persalinan sesuai kewenangan klinis. }\end{array}$ & 5 & 100 \\
\hline & 5 & $\begin{array}{l}\text { e. Perawat atau bidan memfasilitasi pelaksanaan } \\
\text { Inisiasi Menyusu Dini (IMD) sesuai kriteria. }\end{array}$ & 5 & 100 \\
\hline & 6 & $\begin{array}{l}\text { f. Perawat atau bidan melakukan perawatan } \\
\text { bayi baru lahir sesuai dengan standar } \\
\text { prosedur. }\end{array}$ & 5 & 100 \\
\hline & & $\begin{array}{l}\text { g. Perawat atau bidan melakukan pemantau } 2 \\
\text { jam persalinan meliputi ; }\end{array}$ & & \\
\hline & 7 & 1) TTV ibu & 5 & 100 \\
\hline & 8 & 2) Jumlah Perdarahan & 5 & 100 \\
\hline & 9 & 3) Kontraksi uterus & 4 & 80 \\
\hline & 10 & 4) Pengosongan kandung kemih & 3 & 60 \\
\hline & 11 & $\begin{array}{l}\text { h. Perawat atau bidan melakukan dokumentasi } \\
\text { asuhan intranatal. }\end{array}$ & 5 & 100 \\
\hline \multirow{5}{*}{$\begin{array}{l}\text { Manajemen } \\
\text { Nyeri } \\
\text { Persalinan }\end{array}$} & 15 & $\begin{array}{l}\text { a. Perawat atau bidan melakukan pengkajian } \\
\text { nyeri. }\end{array}$ & 4 & 80 \\
\hline & 16 & $\begin{array}{l}\text { b. Perawat atau bidan sesuai kompetensinya } \\
\text { melaksanaan manajemen nyeri dengan terapi } \\
\text { non farmakologi: berbagai teknik sesuai } \\
\text { dengan kesepakatan/kemampuan pasien; } \\
\text { tehnik pernapasan, distraksi, aromatherapy, } \\
\text { penggunaan herbal, hidrotherapi, } \\
\text { hypnobirthing, self massage, TENS, } \\
\text { akupuntur, sesuai dengan SPO }\end{array}$ & 4 & 80 \\
\hline & 17 & $\begin{array}{l}\text { c. Perawat atau bidan berkolaborasi pemberian } \\
\text { terapi medik untuk mengurangi nyeri. }\end{array}$ & 5 & 100 \\
\hline & 18 & $\begin{array}{l}\text { d. Perawat atau bidan melakukan evaluasi } \\
\text { tingkat kepuasan pasien terhadap penurunan } \\
\text { nyeri. }\end{array}$ & 5 & 100 \\
\hline & 19 & $\begin{array}{ll}\text { e. Perawat atau bidan mendokumentasi } \\
\text { pelaksanaan manajemen nyeri persalinan. }\end{array}$ & 5 & 100 \\
\hline \multirow{3}{*}{$\begin{array}{l}\text { Peningkatan } \\
\text { Hubungan Ibu } \\
\text { Dan Bayi } \\
\text { (Bonding } \\
\text { Attachment) }\end{array}$} & 20 & $\begin{array}{l}\text { a. Perawat atau bidan melaksanakan bonding } \\
\text { attachment yang berlaku sesuai dengan } \\
\text { kebijakan }\end{array}$ & 5 & 100 \\
\hline & 21 & $\begin{array}{l}\text { b. Perawat atau bidan merawat ibu dan bayi } \\
\text { dirawat secara berdampingan. }\end{array}$ & 5 & 100 \\
\hline & 22 & $\begin{array}{l}\text { c. Perawat atau bidan melaksankaan edukasi } \\
\text { manajemen laktasi. }\end{array}$ & 2 & 40 \\
\hline
\end{tabular}




\begin{tabular}{ccccc}
\hline & 23 & d. $\begin{array}{l}\text { Perawat atau bidan mengevaluasi respon } \\
\text { pasien setiap selesai melakukan tindakan } \\
\text { keperawatan. }\end{array}$ & 5 & 100 \\
\cline { 2 - 5 } & 24 & $\begin{array}{c}\text { e. } \\
\text { Perawat atau bidan menyusun dokumentasi } \\
\text { evaluasi dalam bentuk SOAP }\end{array}$ & 5 & 100 \\
\hline $\begin{array}{c}\text { Informed } \\
\text { Consent }\end{array}$ & 25 & $\begin{array}{l}\text { Perawat atau bidan melaksanakan informed consent } \\
\text { tindakan keperawatan secara tertulis sesuai kebutuhan }\end{array}$ & 5 & 100 \\
\hline & Jumlah & 102 & 2040 \\
\cline { 2 - 5 } & Rata-rata & 4,636 & 92,7 \\
\hline
\end{tabular}

Berdasarkan tabel 1. Gambaran Proses Pelayanan Asuhan Keperawatan Maternitas Pada Intranatal Spontan di dapatkan data bahwa nilai terendah pada tindakan peningkatan hubungan ibu dan bayi (bounding attachment) yaitu pada pelaksanaan edukasi manajemen laktasi sebesar 40\%. Pelaksanaan standar tersebut masih rendah karena setelah 2 jam postpartum ibu dipindahkan ke ruang nifas, sehingga intervensi dilanjutkan di ruang nifas. Alasan lain adalah intervensi pada 2 jam postpartum lebih difokuskan pada observasi TTV, tanda perdarahan, dan kontraksi uterus. Hal ini diungkapkan oleh beberapa informan salah satu sebagai berikut “........ kalo sudah lahiran biasanya bayi dirawat dulu di perina, sambil si ibu kita bersihkan dulu ya..kalo sudah beres ibu kita observasi lagi TTVnya, perdarahannya, kontraksi uterusnya sampai 2 jam PP kalo udah bagus pindah ke nifas nanti dirawat lanjut lagi disana oleh bidan di ruang nifas...kayaknya kayak gitu aja ya...".

Selain itu, berdasarkan hasil penelitian didapatkan pula proses pelayanan yang belum mencapai $100 \%$ diantaranya adalah untuk asuhan intranatal pada point pemantau 2 jam persalinan hanya $60 \%$ dari perawat atau bidan yang melakukan pengosongan kandung kemih. Hal ini sejalan dengan pernyataan beberapa informan diantaranya adalah "mmm...untuk pemantauan kan 2 jam PP memang kita lakukan seperti TTVnya, perdarahannya, kontraksi uterusnya yang lain ya lanjut di Ruang Nifas aja...", “ pengosongan kandung kemih....ya ditanya saja pasiennya sudah pipis atau belum, tapi.....biasanya itu di Ruang Nifas saja sih ya". Selanjutnya, untuk proses pelayanan yang belum sampai $100 \%$ adalah manajemen persalinan yaitu hanya mencapai $80 \%$. Hal ini sejalan dengan pernyataan beberapa informan diantaranya: "Nyeri persalinan itu pasti dialami ibu yang melahirkan, jerit jerit udah biasa ya....kita sarankan tarik nafas aja", “ nyeri nya pasien beda beda ya....ya kita suruh suaminya mendampingi, suruh atur nafasnya saja"

Proses pelayanan asuhan keperawatan maternitas intranatal SC, berdasarkan hasil penelitian diketahui bahwa dari 9 pasien diketahui, rata-rata pelayanan yang telah diberikan hanya $86,2 \%$ dari semua proses pelayanan dengan rentang antara $80 \%$ - 96\%. Pelaksanaan roses pelayanan pada masingmasing item observasi dilaporkan sebagai berikut : 
Tabel 2.

Gambaran proses pelayanan asuhan keperawatan maternitas pada intranatal $\mathrm{SC}$

\begin{tabular}{|c|c|c|c|c|}
\hline $\begin{array}{c}\text { Standar } \\
\text { Pelayanan }\end{array}$ & No & Item Observasi & Jmlh & $\%$ \\
\hline \multirow{12}{*}{$\begin{array}{l}\text { Asuhan } \\
\text { Intranatal }\end{array}$} & 1 & $\begin{array}{l}\text { a. Perawat atau bidan melakukan pengisian format pengkajian } \\
\text { dan format pemantauan kemajuan persalinan (partograf), } \\
\text { format diagnosis, format perencanaan, format implementasi } \\
\text { dan format evaluasi. }\end{array}$ & 9 & 100 \\
\hline & 2 & $\begin{array}{l}\text { b. Perawat atau bidan melakukan pemantau kesejahteraan janin } \\
\text { dan ibu secara berkala }\end{array}$ & 9 & 100 \\
\hline & 3 & $\begin{array}{l}\text { c. Perawat atau bidan menentukan rencana asuhan intranatal } \\
\text { pada setiap kala persalinan (Kala 1, 2, 3 dan 4) }\end{array}$ & 9 & 100 \\
\hline & 4 & $\begin{array}{l}\text { d. Perawat atau bidan melakukan pertolongan persalinan sesuai } \\
\text { kewenangan klinis. }\end{array}$ & 9 & 100 \\
\hline & 5 & $\begin{array}{l}\text { e. Perawat atau bidan memfasilitasi pelaksanaan Inisiasi } \\
\text { Menyusu Dini (IMD) sesuai kriteria. }\end{array}$ & 4 & 44,4 \\
\hline & 6 & $\begin{array}{l}\text { f. Perawat atau bidan melakukan perawatan bayi baru lahir } \\
\text { sesuai dengan standar prosedur. }\end{array}$ & 9 & 100 \\
\hline & & $\begin{array}{l}\text { g. Perawat atau bidan melakukan pemantau 2jam persalinan } \\
\text { meliputi ; }\end{array}$ & & \\
\hline & 7 & 1) TTV ibu & 9 & 100 \\
\hline & 8 & 2) Jumlah Perdarahan & 9 & 100 \\
\hline & 9 & 3) Kontraksi uterus & 9 & 100 \\
\hline & 10 & 4) Pengosongan kandung kemih & 5 & 55,6 \\
\hline & 11 & $\begin{array}{l}\text { h. Perawat atau bidan melakukan dokumentasi asuhan } \\
\text { intranatal. }\end{array}$ & 9 & 100 \\
\hline \multirow{3}{*}{$\begin{array}{c}\text { Asuhan } \\
\text { Persalinan } \\
\text { Dengan Sc }\end{array}$} & 12 & $\begin{array}{l}\text { a. Perawat atau bidan memberikan penjelsan terkait tentang } \\
\text { prosedur perawatan pada pasien SC }\end{array}$ & 8 & 88,9 \\
\hline & 13 & $\begin{array}{l}\text { b. Perawat atau bidan melakukan persiapan secara fisik bagi } \\
\text { pasien pre operasi SC }\end{array}$ & 9 & 100 \\
\hline & 14 & $\begin{array}{l}\text { c. Perawat atau bidan melakukan persiapan secara psikologis } \\
\text { bagi pasien pre operasi SC }\end{array}$ & 2 & 22,2 \\
\hline \multirow{5}{*}{$\begin{array}{l}\text { Manajemen } \\
\text { Nyeri } \\
\text { Persalinan }\end{array}$} & 15 & a. $\quad$ Perawat atau bidan melakukan pengkajian nyeri. & 9 & 100 \\
\hline & 16 & $\begin{array}{l}\text { b. Perawat atau bidan sesuai kompetensinya melaksanaan } \\
\text { manajemen nyeri dengan terapi non farmakologi: berbagai } \\
\text { teknik sesuai dengan kesepakatan/kemampuan pasien; tehnik } \\
\text { pernapasan, distraksi, aromatherapy, penggunaan herbal, } \\
\text { hidrotherapi, hypnobirthing, self massage, TENS, akupuntur, } \\
\text { sesuai dengan SPO }\end{array}$ & 1 & 11,1 \\
\hline & 17 & $\begin{array}{l}\text { c. Perawat atau bidan berkolaborasi pemberian terapi medik } \\
\text { untuk mengurangi nyeri. }\end{array}$ & 9 & 100 \\
\hline & 18 & $\begin{array}{l}\text { d. Perawat atau bidan melakukan evaluasi tingkat kepuasan } \\
\text { pasien terhadap penurunan nyeri. }\end{array}$ & 9 & 100 \\
\hline & 19 & $\begin{array}{l}\text { e. Perawat atau bidan mendokumentasi pelaksanaan manajemen } \\
\text { nyeri persalinan. }\end{array}$ & 9 & 100 \\
\hline \multirow{5}{*}{$\begin{array}{l}\text { Peningkatan } \\
\text { Hubungan Ibu } \\
\text { Dan Bayi } \\
\text { (Bonding } \\
\text { Attachmen) }\end{array}$} & 20 & $\begin{array}{l}\text { a. Perawat atau bidan melaksanakan bonding attachment yang } \\
\text { berlaku sesuai dengan kebijakan }\end{array}$ & 9 & 100 \\
\hline & 21 & $\begin{array}{l}\text { b. Perawat atau bidan merawat ibu dan bayi dirawat secara } \\
\text { berdampingan. }\end{array}$ & 9 & 100 \\
\hline & 22 & $\begin{array}{ll}\text { c. Perawat atau bidan melaksankaan edukasi manajemen } \\
\text { laktasi. }\end{array}$ & 3 & 33,3 \\
\hline & 23 & $\begin{array}{l}\text { Perawat atau bidan mengevaluasi respon pasien setiap } \\
\text { selesai melakukan tindakan keperawatan. }\end{array}$ & 9 & 100 \\
\hline & 24 & $\begin{array}{l}\text { Perawat atau bidan menyusun dokumentasi evaluasi dalam } \\
\text { bentuk SOAP }\end{array}$ & 9 & 100 \\
\hline
\end{tabular}




\begin{tabular}{cccc}
\hline $\begin{array}{c}\text { Informed } \\
\text { Consent }\end{array}$ & 25 & $\begin{array}{l}\text { Perawat atau bidan melaksanakan informed consent tindakan } \\
\text { keperawatan secara tertulis sesuai kebutuhan }\end{array}$ & 9 \\
\hline & Jumlah & 100 \\
\cline { 2 - 3 } & Rata-rata & 7,76 \\
\cline { 2 - 3 } & Persentase & 86,2 \\
\hline
\end{tabular}

Berdasarkan pada tabel 2 , diperoleh gambaran proses pelayanan pada pasien intranatal dengan SC didapatkan hasil bahwa masih terdapat beberapa tindakan keperawatan yang dilakukan oleh petugas kesehatan di bawah ratarata, dengan persentasi terendah $(11,1 \%)$ pada manajemen nyeri persalinan. Hal ini, diperkuat oleh pernyataan bidan bahwa pasien bersalin dengan SC lebih banyak karena kegawatan saat persalinan dan segera diberikan tindakan. Hal ini sejalan dengan ungkapan salah satu partisipan yang sebagai berikut "Rata-rata pasien SC kan yang harus segera atau ada indikasi, di kita biasanya ga lama...langsung kirim OK”, "ooo kalo nyeri ya.....kalo yang normal mah fisiologis paling disuruh tarik nafas dalam aja....tapi kalo yang sc kan biasanya cito jadi ga sempet banyak intervensi".

Gambaran lain yang diperoleh berdasarkan hasil analisis diatas item yang masih di bawah rata-rata adalah tentang persiapan secara psikologis pada pasien SC hanya 22, 2\%. Hasil ini sesuai dengan pernyataan perawat yang mengungkapkan bahwa proses pelayanan pada pasien SC diantaranya adalah "Ooo kalo SC informed consent ke pasiennya sebelum melakukan tindakan apa tindakan yang akan dikerjakan kemudian setelah itu kan kita ada kayak pemasangan kateter, kemudian persiapan sebelum pre opnya kita lakukan, seperti pencukuran masih kita lakukan”, "ya kita lakukan persiapan pertama informed consent, lanjut misal pemasangan kateter, pencukuran dan lain lain ya udah kalo cito biasanya kita bawa ke OK”, "Kalo yang SC ya biasanya kita kasih tau, lakukan persiapan, informed consent, Kalo engga cyto, kasih tau ibunya jangan tegang...nanti ibu akan di anastesi ekh,,,di bius dari belakang nanti ibu akan merasakan mati rasa, ibu jangan tegang, nanti ibu terlentang nanti mendengar suara bayi dan proses selesai paling gitu aja".

Hasil lain dari penelitian berdasarkan tabel diatas didapatkan bahwa hanya $40 \%$ pada pasien SC yang di fasilitasi Inisiasi Menyusui Dini (IMD), hal ini sejalan dengan yang diungkapkan oleh partisipan yaitu "IMD ya...kalo yang normal APGARnya bagus ya kita lakukan kalo yg di SC yang kondisinya bagus ya dilakukan juga sepertinya..kan di OK ya...pokonya gimana kondisi..."

2) Kepuasan Pasien Terhadap Pelayanan Intranatal

Data lain yang didapat dari penelitian ini adalah hasil analisa outcome kualitas pelayanan asuhan keperawatan maternitas ada pelayanan intranatal. hasil penelitian menunjukkan bahwa dari 5 pasien diketahui rata-rata kepuasan pasien terhadap pelayanan intranatal spontan mencapai 70,1\% dengan rentang antara $60,00 \%-80,00 \%$. Pada pelayanan intranatal SC menunjukkan bahwa 
dari 9 pasien diketahui rata-rata kepuasan pasien terhadap pelayanan intranatal SC mencapai $71,8 \%$ dengan rentang antara $66,7 \%-77,8 \%$.

Tabel 3

Gambaran kepuasan pasien pada pelayanan asuhan keperawatan maternitas pada periode intranatal

\begin{tabular}{ccccc}
\hline Jenis Pelayanan & n & Mean & $\begin{array}{c}\text { Std. } \\
\text { Deviasi }\end{array}$ & $\begin{array}{c}\text { Minimum - } \\
\text { Maksimum }\end{array}$ \\
\hline Pelayanan Intranatal Spontan & 5 & 70,71 & 10,15 & $60,71-85,71$ \\
\hline Pelayanan Intranatal SC & 9 & 71,83 & 5,91 & $58,93-80,36$ \\
\hline
\end{tabular}

Berikut peneliti uraikan pelayanan yang diberikan berkaitan dengan kepuasan pasien pada masing-masing item standar.

Tabel 3

Gambaran kualitas pelayanan berdasarkan unsur pelayanan pada intranatal

\begin{tabular}{|c|c|c|c|c|c|}
\hline \multirow{3}{*}{ No. } & \multirow{3}{*}{ Item Pelayanan } & \multicolumn{4}{|c|}{ Intranatal } \\
\hline & & \multicolumn{2}{|c|}{ Spontan } & \multicolumn{2}{|c|}{$\mathrm{SC}$} \\
\hline & & $\ddot{\mathbf{x}}$ & $\%$ & $\ddot{\mathbf{x}}$ & $\%$ \\
\hline 1 & Kemudahan prosedur pelayanan di unit ini. & 3,0 & 75,0 & 2,8 & 69,4 \\
\hline 2 & $\begin{array}{l}\text { Kesesuaian persyaratan pelayanan dengan jenis } \\
\text { pelayanannya }\end{array}$ & 3,0 & 75,0 & 3,0 & 75,0 \\
\hline 3 & Kejelasan dan kepastian petugas yang melayani. & 3,0 & 75,0 & 2,8 & 69,4 \\
\hline 4 & Kedisiplinan petugas dalam memberikan pelayanan & 2,6 & 65,0 & 2,7 & 66,7 \\
\hline 5 & Tanggung jawab petugas dalam memberikan pelayanan & 2,8 & 70,0 & 2,9 & 72,2 \\
\hline 6 & Kemampuan petugas dalam memberikan pelayanan. & 3,0 & 75,0 & 3,0 & 75,0 \\
\hline 7 & Kecepatan pelayanan di unit ini & 2,8 & 70,0 & 2,8 & 69,4 \\
\hline 8 & Keadilan untuk mendapatkan pelayanan di unit ini. & 2,6 & 65,0 & 2,8 & 69,4 \\
\hline 9 & $\begin{array}{l}\text { Kesopanan dan keramahan petugas dalam memberikan } \\
\text { pelayanan }\end{array}$ & 2,4 & 60,0 & 2,8 & 69,4 \\
\hline 10 & Kewajaran biaya untuk mendapatkan pelayanan & 2,6 & 65,0 & 3,1 & 77,8 \\
\hline 11 & $\begin{array}{l}\text { Kesesuaian antara biaya yang dibayarkan dengan biaya } \\
\text { yang telah ditetapkan }\end{array}$ & 2,8 & 70,0 & 2,9 & 72,2 \\
\hline 12 & Ketepatan pelaksanaan terhadap jadwal waktu pelayanan & 2,6 & 65,0 & 2,8 & 69,4 \\
\hline 13 & Kenyamanan di lingkungan unit pelayanan & 3,2 & 80,0 & 3,0 & 75,0 \\
\hline \multirow[t]{5}{*}{14} & Keamanan pelayanan di unit ini & 3,2 & 80,0 & 3,0 & 75,0 \\
\hline & Rata-rata & 2,8 & 70,7 & 2,9 & 71,8 \\
\hline & Std Deviasi & 0,25 & 6,157 & 0,13 & 3,243 \\
\hline & Minimum & 2,4 & 60,0 & 2,7 & 66,7 \\
\hline & Maksimum & 3,2 & 80,0 & 3,1 & 77,8 \\
\hline
\end{tabular}

Berdasarkan hasil penelitian, didapatkan gambaran bahwa rata-rata kualitas pelayanan berdasarkan unsur kepuasaan pasien pada intranatal spontan yaitu $70,7 \%$ dan pada intranatal SC $71.8 \%$. Hasil penelitian tersebut menunjukan bahwa kualitas pelayanan intranatal di RS. Dustira berada pada kategori baik, karena rata-rata nilai diatas 62,51 menggunakan interpretasi nilai Nilai Rata-Rata dan Indeks Kepuasaan Masyarakat berdasarkan Kepmenpan Nomor Kep/25/M.PAN/2/2004 tentang Pedoman Umum Penyusunan Indeks Kepuasan Masyarakat Unit Pelayanan Instansi Pemerintah. 


\section{b. Pembahasan}

\section{1) Proses pelayanan asuhan keperawatan maternitas pada periode intranatal}

Proses pelayanan di intranatal pada RS Tipe B ini mencapai standar yang tinggi, artinya hampir seluruh indikator dilaksanakan, namun masih ada tindakan yang dibawah rata-rata diantaranya :

a) Pengosongan kandung kemih

Pada asuhan intranatal, dalam 24 jam pertama pasca persalinan sangat penting bagi tenaga kesehatan untuk memberikan Keperawatan yang tepat dengan mengidentifikasi masalah yang berhubungan dengan sistem perkemihan salah satu diantaranya adalah pemantauan pengosongan kandung kemih. Hal ini disebabkan karena kandung kemih dalam puerperium akan berkurang sensitifitasnya sedangkan kapasitasnya bertambah, sehingga kandung kemih penuh dan setelah BAK masih tertinggal urine residual (normal $+15 \mathrm{cc}$ ). Sisa urine dan trauma pada kandung kemih waktu persalinan memudahkan terjadinya infeksi (Novianti, 2015). Selain itu, penelitian yang dilakukan Lestari tahun 2015 diambil dari Sarwono tahun 2009 mengatakan bahwa pada masa nifas terjadi perubahan fisiologis yang menyebabkan rasa tidak nyaman pada masa nifas yang seringkali dijumpai salah satunya adalah perubahan sistem perkemihan termasuk infeksi saluran kemih, retensi urine atau inkontinensia. Masalah lain yang dapat muncul akibat distensi pada kandung kemih pada ibu post partum adalah akan menyebabkan terhambatnya kontraksi uterus sehingga mengakibatkan perdarahan.

Perdarahan merupakan salah satu indikator penyebab tingginya Angka Kematian Ibu, pernyataan ini didukung oleh data yang menyebutkan bahwa $75 \%$ yang menyebabkan hampir $75 \%$ dari semua kematian ibu adalah perdarahan hebat setelah melahirkan, infeksi, tekanan darah tinggi selama kehamilan (pre-eklampsia dan eklampsia), komplikasi dari persalinan, dan aborsi yang tidak aman (Bray et al., 2018). Pengosongan kandung kemih bukan hanya harus dilakukan pada ibu post partum spontan tetapi pada ibu dengan kelhiran SC. Efek samping pada persalinan sectio caesaria menggunakan anestesi spinal berhubungan dengan sistem kerja anestesi, yang menyebabkan terhambatnya hantaran impuls dalam jaringan yang dapat tereksitasi. (Baumert et al., 2009) Pasca SC pasien yang pulih dari anestesi dan analgetik kemungkinan tidak mampu merasakan bahwa kandung kemihnya penuh dan tidak mampu memulai berkemih. Hal ini menyebabkan gangguan kebutuhan eliminasi urine sehingga terjadi retensi urine yaitu penumpukan urine dalam kandung kemih. Penyebab retensi urine antara lain operasi pada abdomen bawah, pelvis vesika urinaria, trauma sumsum tulang belakang, tekanan uretra yang tinggi karena otot detrusor yang lemah, sphincter yang kuat dan sumbatan (Hidayati, 2018). 
Pengosongan kandung kemih pada asuhan intranatal merupakan intervensi yang harus dilaksanakan sedini mungkin dalam upaya mencegah komplikasi pada ibu post partum dimulai dari 2 jam pertama saat di ruang bersalin dan berlanjut saat di ruang nifas. Intervensi non farmakologis yang dapat dilaksanakan dalam upaya pengosongan kandung kemih menurut beberapa penelitian diantaranya adalah 1) Bladder training (Navisah \& Astuti, 2017), (Saputra, 2019), (Wulaningsih, 2017), 2) Kegel exercise (Hidayati, 2018), (Agustin, 2017).

b) Tindakan peningkatan hubungan ibu dan bayi (bounding attachment) dan inisiasi menyusui dini

Ikatan kasih sayang antara ibu dan anak atau bounding attachment mulai terbentuk sejak dalam kandungan, dan akan semakin erat setelah anak lahir. Proses kasih sayang merupakan sesuatu yang linier, dimulai saat ibu hamil, semakin menguat pada awal periode pasca partum, dan begitu terbentuk akan menjadi konstan dan konsisten. Hal ini sangat penting bagi kesehatan fisik dan mental sepanjang rentang kehidupan (Pikhart et al., 2004). Kegagalan proses bounding attachment dapat menyebabkan berkurangnya stimulus yang positif yang berasal dari ibu sehingga dapat mempengaruhi proses perkembangan otak bayi. Pernyataan ini sejalan dengan Penelitian Klaus dan Kennel, mengatakan bahwa para ibu yang diberikan waktu lebih banyak untuk mengadakan kontak dengan anaknya, akan mempunyai kedekatan yang lebih intensif, sehingga menumbuhkan saling kepercayaan antara ibu dan bayi.

Keberhasilan pelaksanaan bounding attachment didukung oleh beberapa faktor yaitu : kesehatan emosional orangtua; tingkat kemampuan, komunikasi, dan kerampilan untuk merawat anak; Dukungan sosial seperti keluarga, teman, dan pasangan; kedekatan orang tua dan anak; kesesuaian orang tua dan anak (keadaan anak, jenis kelamin) (Kurniawan, Sofyani, \& Rahmawati, 2018), (Shariat \& Abedinia, 2017), (Murziqin et al., 2018). Inisiasi Menyusu Dini (IMD) merupakan salah satu cara dalam menfasilitasi bounding attachment (Bobak, Lowdermilk, Jensen, \& Perry, 2005). Pernyataan tersebut sejalan dengan hasil (Nurhidayati, 2018) yang berjudul " Keberhasilan Bounding Attachment Melalui Proses Inisiasi Menyusui Dini”. Hasil penelitian menyebutkan bahwa dari 20 responden yang dilakukan inisiasi menyusu dini terdapat 18 responden yang bounding attachment positif, atau dengan kata lain ada hubungan inisiasi menyusui dini dengan keberhasilan bounding attachment $\mathrm{p}$ value $(0,002<$ 0,05). Berdasarkan hal tersebut untuk mengoptimalisasi proses bounding attachment dapat dilaksanakan dengan memaksimalkan IMD di Ruang bersalin. 
c) Manajemen nyeri

Pada kedua proses pemberian pelayanan asuhan keperawatan intranatal yaitu manajemen nyeri persalinan. Nyeri persalinan merupakan pengalaman ibu hamil pada fase kelahiran bersifat subjektif yang berbedabeda antar individu, tergantung pada bagaimana definisi yang diungkapkan tentang nyeri yang dirasakan (Sri Puji Rahayu Ningsih, 2018). Nyeri persalinan terjadi karena kontraksi uterus, hal ini kemudian akan memicu respons stress tubuh, seperti konsumsi oksigen yang meningkat, hiperventilasi, peningkatan tekanan darah, dan mengganggu pengosongan lambung.

Adanya perbedaan respon nyeri pada persalinan juga dipengaruhi oleh pengalaman masa lalu, kecemasan, dan ketegangan emosi (Tay et al., 2007), (Pikhart et al., 2004). Berdasarkan pengalaman, setiap individu akan mengembangkan berbagai mekanisme untuk mengatasinya. Pada saat menjalani proses persalinan ibu akan mengalami ketegangan emosi akibat kecemasan dan ketakutan terhadap proses persalinan sehingga hal ini akan memperberat persepsi nyeri, begitu pun sebaliknya nyeri menginduksi ketakutan yang menyebabkan kecemasan dan dapat berakhir dengan kepanikan. Hal ini selanjutnya dapat mempengaruhi keputusan ibu untuk menentukan tipe persalinan, pada pasien primigravida, rasa nyeri dapat mendesak ibu untuk memilih tindakan operatif. Pada studi oleh (Bardeesy et al., 2002) dilaporkan bahwa sebanyak 37,2 \% ibu memilih tindakan sectio caesaria karena ketakutan akan rasa nyeri saat persalinan.

Metode yang dapat dilaksanakan oleh seorang perawat atau bidan dalam mengurangi nyeri adalah metode terapi non-farmakologi, selain menurunkan rasa nyeri, terapi non-farmakologi diduga juga dapat mendorong komponen psikoemosional dan spiritual sehingga dapat meningkatkan kesiapan pasien dalam bersalin. Beberapa metode terapi non-farmakologi yang dapat digunakan, seperti masase dan sentuhan, pergerakan dan posisi, teknik bernapas dengan relaksasi, aplikasi panas / dingin, dan terapi musik. Berbagai pemilihan tentang tekhnik untuk mengurangi nyeri pada proses persalinan harus diberikan pada ibu, mengingat nyeri merupakan perasaan subjektifitas dari individu, sehingga tidak akan menimbulkan gangguan atau komplikasi.

d) Persiapan psikologis pada pasien SC

Persiapan psikologis pada pasien SC merupakan salah satu prioritas keperawatan yang bertujuan untuk menurunkan kecemasan sehingga dapat mengurangi resiko post operasi (Smeltzer \& Bare, 2002). Kecemasan terjadi karena adanya perubahan sosial yang sangat cepat, seseorang tanpa persiapan yang cukup harus menjalani situasi baru sehingga pasien tidak mampu untuk beradaptasi dengan kondisi yang dihadapinya atau karena situasi ini merupakan pengalaman pertamanya (Videbeck, 2008) 
Kecemasan pre operasi yang tidak terkontrol akan menjadi gangguan dalam tubuh sehingga mempengaruhi stimulasi sistem syaraf simpatis yang berefek meningkatkan frekuensi darah, curah jantung dan tahanan perifer selanjutnya akan berakiba pada peningkatan tekanan dara, yang bisa menyebabkan perdarahan baik saat pembedahan atau pun pasca SC (Kozier et al., 2011). Kecemasan pre operasi juga membuat pernapasan meningkat dan vasokonstriksi pada pembuluh darah lambung (Maryunani, 2014). Individu yang mengalami kecemasan akan mengalami keluhankeluhan seperti cemas, khawatir, firasat buruk, takut akan pikiran sendiri, mudah tersinggung, merasa tegang, tidak tenang, gelisah, mudah terkejut, gangguan pola tidur, mimpi-mimpi yang menegangkan, gangguan konsentrasi dan daya ingat (Johan, Suan, Hawari, \& Ching, 2011).

Berdasarkan hal tersebut diatas, selain persiapan secara fisik pada pasien pre operasi, penting untuk melakukan persiapan secara psikologis. Beberapa penelitian tentang intervensi untuk menurunkan kecemasan diantaranya 1) Pendidikan Kesehatan (Sahara \& Hutasoit, 2018), (Wahyuni, 2017) Terapi musik (Keumalahayati \& Supriyanti, 2018), (Maiseptyasari, 2019).

2) Kepuasan pasien

Berdasarkan hasil penelitian bahwa kepuasan pasien di RS ini belum mencapai target kepuasan pelanggan, namun berdasarkan pada kualitas pelayanan rata-rata berada pada ketegori baik berdasarkan Indeks Kepuasan Masyarakat. Mutu sebuah pelayanan kesehatan termasuk pelayanan asuhan keperawatan maternitas periode intranatal sangat bergantung pada sudut pandang, latar belakang, pendidikan, pengetahuan, pekerjaan, pengalaman, lingkungan, dan kepentingan setiap orang yang terlibat dalam pelayanan. Hal tersebut memungkinkan perbedaan pandangan dan penilaian dari setiap unsur yang terlibat dalam pelayanan salah satunya pasien sebagai penerima pelayanan. Pandangan pasien terhadap pelayanan kesehatan, dikatakan bermutu apabila pelayanan tersebut dapat memenuhi kebutuhan kesehatannya, mampu menyembuhkan keluhannya serta mencegah berkembangnya atau meluasnya penyakit. Pasien juga memiliki harapan dan pandangan bahwa kualitas pelayanan yang baik apabila diselenggarakan dengan cara yang sopan dan santun, tepat, waktu, tanggap dan. Prsepektif pasien merupakan salah satu faktor yang mempengaruhi kualitas suatu pelayanan dan pada akhirnya pasien yang merasa puas akan mematuhi proses pengobatan dan akan melakukan kunjungan ulang sehingga dapat meningkatkan derajat kesehatan masyarakat.

Kepuasan pasien merupakan suatu perasaan pasien pada tingkat tertentu yang disebabkan dari kinerja pemberi pelayanan dan apa yang diharapkan pasien terhadap pelayanan (Pohan, 2013). Penelitian Andriani, 2016 yang berjudul "Hubungan Mutu Pelayanan Kesehatan Dengan Kepuasan Pasien Di Ruang Poli Umum Puskesmas Bukit Tinggi”, menyebutkan hasil bahwa terdapat hubungan 
antara kualitas mutu pelayanan kesehatan dengan kepuasan pasien. Dalam penelitian tersebut di jelaskan pula bahwa kepuasan pasien berhubungan dengan pemahaman penerima pelayanan terhadap produk jasa yang diberikan terhadap apa yang diharapkan. Sehingga kepuasan pasien tidak hanya mengacu pada standar dan proses pemberian pelayanan saja tetapi dipengaruhi pula oleh pemahaman pasien terhadap pelayanan itu sendiri. Setiap unsur dalam pelayanan berhubungan satu dengan yang lain, pernyataan ini mengandung makna bahwa setiap pemberi pelayanan berusaha untuk memenuhi kebutuhan para penerima pelayanan, sedangkan penerima pelayanan akan berusaha untuk memenuhi harapan dari pelayanan yang diterimanya. Hal tersebut diatas sejalan dengan penelitian yang dilakukan oleh (Suryati, Widjanarko, \& Istiarti, 2017) yang berjudul Faktor-Faktor yang Berhubungan Dengan Kepuasan Pasien BPJS terhadap Pelayanan Rawat Jalan di Rumah Sakit Panti Wilasa Citarum Semarang, yang menyebutkan bahwa selain faktor pemberi pelayanan bahwa karakteristik pasien (umur dan pendidikan) juga juga berhubungan dengan kepuasan pasien.

\section{Kesimpulan}

Hasil peneltian didapatkan data bahwa pelayanan Asuhan Keperawatan (Askep) Maternitas pada pelayanan intranatal spontan didapatkan data, rata-rata 92,73\% dengan rentang antara 90,91\% - 95,45\%, sedangkan pada pasien SC rata-rata pelayanan yang telah diberikan hanya $86,2 \%$ dari semua proses pelayanan dengan rentang antara $80 \%-$ 96\%. Hal ini menujukan bahwa proses pelayanan pada periode intranal di salah satu RS. Tipe B Kota Cimahi ini belum optimal, atau masih ada beberapa yang belum dilaksanakan sesuai dengan standar pada pelayanan intranatal, diantaranya adalah pelaksanaan edukasi manajemen laktasi sebesar, pengosongan kandung kemih, bounding attachment, manajemen nyeri persalinan, persiapan psikologis pada pasien SC, dan inisiasi menyusui dini. Pelaksanaan standar yang belum optimal berdasarkan persepsi perawat lebih dikarenakan kondisi pasien yang harus segera dilakukan tindakan dan beberapa tindakan yang dilanjutkan diruang nifas. Berdasarkan hasil penelitian pada outcome pelayanan asuhan keperawatan maternitas periode intranatal didapatkan data bahwa kepuasan pasien di RS ini rata-rata kualitas pelayanan berdasarkan unsur kepuasaan pasien pada intranatal spontan yaitu 70,7\% dan pada intranatal SC $71.8 \%$. Hasil penelitian tersebut menunjukan bahwa kualitas pelayanan intranatal di RS. Dustira berada pada kategori baik, karena rata-rata nilai diatas 62,51. 


\section{BIBLIOGRAFI}

Agustin, Rohma Yuni. (2017). Gambaran Kemampuan Fungsi Eliminasi Urine Pada Ibu Postpartum Sectio Caesarea (Studi Pada Ibu Yang Melakukan Kegel Exercise). University of Muhammadiyah Malang.

Bardeesy, Nabeel, Sinha, Manisha, Hezel, Aram F., Signoretti, Sabina, Hathaway, Nathaniel A., Sharpless, Norman E., Loda, Massimo, Carrasco, Daniel R., \& DePinho, Ronald A. (2002). Loss of the Lkb1 tumour suppressor provokes intestinal polyposis but resistance to transformation. Nature, 419(6903), 162-167.

Baumert, Jürgen, Blum, Werner, Brunner, Martin, Dubberke, Thamar, Jordan, Alexander, Klusmann, Uta, Krauss, Stefan, Kunter, Mareike, Löwen, Katrin, \& Neubrand, Michael. (2009). Professionswissen von Lehrkräften, kognitiv aktivierender Mathematikunterricht und die Entwicklung von mathematischer Kompetenz (COACTIV): Dokumentation der Erhebungsinstrumente. Max-PlanckInstitut für Bildungsforschung.

Bobak, Irene M., Lowdermilk, Deltra Leonard, Jensen, Margaret D., \& Perry, S. E. (2005). Buku ajar keperawatan maternitas. Jakarta: EGC.

Bray, Freddie, Ferlay, Jacques, Soerjomataram, Isabelle, Siegel, Rebecca L., Torre, Lindsey A., \& Jemal, Ahmedin. (2018). Global cancer statistics 2018: Globocan estimates of incidence and mortality worldwide for 36 cancers in 185 countries. CA: A Cancer Journal for Clinicians, 68(6), 394-424.

Gillies, Stephen D., Lo, Kin Ming, \& Wesolowski, John. (1989). High-level expression of chimeric antibodies using adapted cDNA variable region cassettes. Journal of Immunological Methods, 125(1-2), 191-202.

Hidayati, Anis. (2018). Pengaruh pemberian kegel exercise terhadap tingkat inkontinensia urine pada ibu Post Partum (Study Di Ruang Gayatri RSUD Dr Wahidin Sudiro Husodo Kota Mojokerto Tahun 2018). STIKES Insan Cendekia Medika Jombang.

Johan, Mohd Rafie, Suan, Mohd Shahadan Mohd, Hawari, Nor Liza, \& Ching, Hee Ay. (2011). Annealing effects on the properties of copper oxide thin films prepared by chemical deposition. Int. J. Electrochem. Sci, 6(12), 6094-6104.

Kemenkes, R. I. (2015). Profil kesehatan Indonesia tahun 2014. Jakarta: Kemenkes RI.

Keumalahayati, Keumalahayati, \& Supriyanti, Supriyanti. (2018). Pengaruh Terapi

Musik Klasik Beethoven untuk Mengurangi Kecemasan pada Ibu Bersalin Pre Operasi Sectio Caesar. JKEP, 3(2), 96-107.

Kozier, Barbara, Erb, Glenora Lea, Berman, Audrey, Snyder, Shirlee, Levett-Jones, Tracy, Dwyer, Trudy, Hales, Majella, Harvey, Nichole, Luxford, Yoni, \& Moxham, Lorna. (2011). Kozier \& Erb's Fundamentals of Nursing Australian Edition. Pearson Higher Education AU. 
Kurniawan, Tedy, Sofyani, Hafiez, \& Rahmawati, Evi. (2018). Pengungkapan Sustainability Report dan nilai perusahan: Studi Empiris di Indonesia dan Singapura. Kompartemen: Jurnal Ilmiah Akuntansi, 16(1).

Maiseptyasari, Ruri. (2019). Pengaruh terapi musik terhadap tingkat kecemasan Pasien Pre Operasi Sectio Caesaria di RSUD Curup. Jurnal Ilmiah Kesehatan Ar-Rum Salatiga, 3(2).

Maryunani, N. (2014). Asuhan keperawatan perioperatif-pre operasi (menjelang pembedahan). Jakarta: Trans Info Media.

Moog, R., Learning, P. O. G. I., \& Student-Centered, A. (2017, February). Science Education Keynote. In 11th Annual TN STEM Education Research Conference February 2-3, 2017 DoubleTree Hotel Murfreesboro, TN (p. 6).

Murziqin, Ramzi, ZA, Tabrani, el-Vanthuny, Syahril, Qamariah, Hijjatul, Sung, Wang Yean, Huda, Miftachul, Mendoza, Peter Jon Loyola, Wekke, Ismail Suardi, Idris, Saifullah, \& Furqani, Hafas. (2018).

Navisah, Fitrotun, \& Astuti, Rahayu. (2017). Perbedaan efektivitas mobilisasi dini dan bladder training terhadap waktu eliminasi bak pertama pada Ibu Post Sectio Caesarea Di RSUD DR. H. Soewondo Kendal. Jurnal Ilmu Keperawatan dan Kebidanan, 9(2).

Novianti, Dewi. (2015). Kemampuan daya hambat ekstrak buah mengkudu (Morinda citrifolia) terhadap bakteri shigella dysenteriae. Sainmatika: Jurnal Ilmiah Matematika Dan Ilmu Pengetahuan Alam, 12(1).

Nurhidayati, Novita. (2018). Keberhasilan bounding attachment melalui proses inisiasi menyusui dini. Jurnal Kebidanan, 10(02), 153-161.

Pikhart, Hynek, Bobak, Martin, Pajak, Andrzej, Malyutina, Sofia, Kubinova, Ruzena, Topor, Roman, Sebakova, Helena, Nikitin, Yuri, \& Marmot, Michael. (2004). Psychosocial factors at work and depression in three countries of Central and Eastern Europe. Social Science \& Medicine, 58(8), 1475-1482.

Pohan, Imbola S. (2013). Jaminan mutu layanan kesehatan. Jakarta: EGC.

Rahayuwati, Laili, Ermiati, E., \& Trisyani, Mira. (2016). process evaluation: standard, effectiveness, efficiency and sustainability of maternity nursing care. Jurnal Keperawatan Padjadjaran, 4(2).

Sahara, Maya, \& Hutasoit, Lastriniwati. (2018). Pengaruh edukasi persiapan pre operasi terhadap tingkat kecemasan pasien Pre Operasi Di Ruang Bedah RSU UKI Tahun 2017. Jurnal Antara Keperawatan, 1(1).

Saputra, Rahmat Andi. (2019). Analisis asuhan keperawatan penerapan bladder training untuk mencegah retensi urine pada pasien post sectio caesarea di ruang Flamboyan 
Rsud Prof. Dr. Margono Soekarjo Purwokerto. Stikes Muhammadiyah Gombong.

Sari, Devi Melyana. (2014). Evaluasi kinerja penyelenggaraan pelatihan Emergency Nursing 2 BAPELKES Batam dalam pemenuhan kompetensi aparatur kesehatan. Jurnal Administrasi Publik Dan Birokrasi, 1(2), 72186.

Shariat, Mamak, \& Abedinia, Nasrin. (2017). The effect of psychological intervention on mother-infant bonding and breastfeeding. Iranian Journal of Neonatology IJN, $8(1), 7-15$.

Simarmata, Oster Suriani, Armagustini, Yetti, \& Bisara, Dina. (2012). Determinan kejadian komplikasi persalinan di Indonesia (analisis data sekunder survei demografi dan kesehatan Indonesia tahun 2007). Indonesian Journal of Health Ecology, 11(1), 79711.

Smeltzer, Suzanne C., \& Bare, Brenda G. (2002). Buku ajar keperawatan medikal bedah. Jakarta: Egc, 1223, 21.

Sri Puji Rahayu Ningsih, Goa517040. (2018). Pemberian kompres hangat terhadap penurunan nyeri persalinan pada asuhan keperawatan $\mathrm{Ny}$. V dengan persalinan normal kala I Dipuskesmas Keling I Jepara. Universitas Muhammadiyah Semarang.

Suryati, Suryati, Widjanarko, Bagoes, \& Istiarti, V. G. Tinoek. (2017). Faktor-faktor yang berhubungan dengan kepuasan pasien BPJS terhadap Pelayanan rawat jalan di rumah sakit Panti Wilasa Citarum Semarang. Jurnal Kesehatan Masyarakat (eJournal), 5(5), 1102-1112.

Tay, Tat Wei, Andriana, Bibin Bintang, Ishii, Maki, Tsunekawa, Naoki, Kanai, Yoshiakira, \& Kurohmaru, Masamichi. (2007). Disappearance of vimentin in Sertoli cells: a mono (2-ethylhexyl) phthalate effect. International Journal of Toxicology, 26(4), 289-296.

Videbeck, Sheila L. (2008). Buku ajar keperawatan jiwa. Jakarta: Egc, 45, 2010-2011.

Wahyuni, Sri. (2017). Efektivitas pemberian pendidikan kesehatan dan terapi murottal al-qur'an terhadap tingkat kecemasan pasien pre operasi bph di RS PKU Muhammadiyah Gombong. Stikes Muhammadiyah Gombong.

Wulaningsih, Indah. (2017). Pengaruh Bladder Training terhadap kemampuan ibu postpartum sectio caesarea dalam berkemih di Rsud Kajen Kabupaten Pekalongan. Jurnal Smart Keperawatan, 4(1). 